\title{
27. DETRITAL MINERALS IN SURFACE SEDIMENTS FROM HESS DEEP, EQUATORIAL PACIFIC: IMPLICATIONS FOR THE LITHOLOGIC SPREAD OF MAFIC-ULTRAMAFIC ROCKS ${ }^{\wedge}$
}

\author{
Shoji $\mathrm{Arai}^{2}$ and Natsue $\mathrm{Abe}^{2}$
}

\begin{abstract}
Surface sediments from Holes 894D, 894E, and 895A of ODP Leg 147 were examined for chromian spinel and other detrital minerals in order to determine the source rocks of the Hess Deep sediments. The detrital chromian spinel, except for that in basalt particles, has an intermediate $\mathrm{Cr} \#(=\mathrm{Cr} /[\mathrm{Cr}+\mathrm{Al}]$ atomic ratio), similar to spinel in ultramafic-mafic plutonic rocks drilled at Site 895. Chromian spinel derived from peridotites and related mafic plutonic rocks was not found in sediments from Site 894. Detrital spinel from Site 895 is generally low in Ti, which indicates a derivation mainly from harzburgite or peridotite intermediate between harzburgite and dunite, that is, a slightly melt-impregnated harzburgite. The peridotites that supplied the clastic particles represent less melt-impregnated rocks than the peridotites cored at Site 895. Lherzolitic peridotites, which have chromian spinel with $\mathrm{Cr} \#<0.4$ and are predominant in the Atlantic fracture zones, are absent in Hess Deep.
\end{abstract}

\section{INTRODUCTION}

Some serpentinite breccias or sandstones form near serpentinite exposures or cliffs in the ocean floor, especially at oceanic fracture zones (e.g., Bonatti et al., 1973, 1974). Some detrital minerals, especially chromian spinel and clinopyroxene, in sediments can be a good petrographic indicator of the source rocks (e.g., Arai et al., 1983; Arai and Okada, 1991). These minerals can provide information on the spatial lithologic variation of presently exposed rocks or on the lithology of rocks lost by erosion. The chemical composition of chromian spinel is affected by the physicochemical conditions of its crystallization and is a good petrogenetic indicator for mafic-ultramafic rocks (Irvine, 1967; Jackson, 1969; Evans and Frost, 1975; Dick and Bullen, 1984; Arai, 1992).

During Ocean Drilling Program (ODP) Leg 147, mafic and ultramafic plutonic rocks were recovered from Sites 894 and 895, at Hess Deep in the equatorial Pacific. Submersible surveys indicate that gabbroic rocks (both cumulate and noncumulate) and, less commonly, basaltic rocks are exposed around Site 894 (Francheteau et al., 1990). On the other hand, both peridotites (harzburgite and dunite) and cumulate gabbros are exposed around Site 895 (Francheteau et al., 1990, 1992). Drilling results from Leg 147 are consistent with the submersible observations. Gabbroic rocks and ultramafic rocks were obtained mostly from Sites 894 and 895, respectively (Gillis, Mével, Allan, et al., 1993). No ultramafic rocks were cored at Site 894. The cores from Site 895 are dominated by ultramafic rocks with intervening gabbroic and troctolitic rocks; harzburgite is predominant over dunite in core from Hole $895 \mathrm{D}$ and vice versa in core from Hole $895 \mathrm{E}$ (Gillis, Mével, Allan, et al., 1993).

Drilling through the ocean floor clarifies the vertical lithologic variation at each hole. The petrography of the surface sediments may provide information on the spatial lithologic variation for exposed rocks, if any. Some detrital minerals, including chromian spinel, in the surface sediments obtained from Holes 894D, 894E, and 895A

Mével, C., Gillis, K.M., Allan, J.F., and Meyer, P.S. (Eds.), 1996. Proc. ODP, Sci. Results, 147: College Station, TX (Ocean Drilling Program).

'Department of Earth Sciences, Faculty of Science, Kanazawa University, Kakumamachi, Kanazawa 920-11, Japan. were examined in order to estimate the lithologic spread of the exposed rocks around each site.

\section{PETROGRAPHY OF THE SEDIMENTS Hole 894D}

Sample 147-894D-1R-1, 129-130 cm, was examined. The sediments are composed of subangular to rounded, fine- to mediumgrained sand particles of mafic effusive rocks with abundant calcareous materials. Basaltic particles are typically glassy and aphyric and brown in thin section. Fine-grained basalt with acicular plagioclase was also found. Olivine is prominent as a detrital mineral grain.

Olivine, plagioclase, hornblende, and augite were found as detrital mineral particles. Olivine is clear and has rare, small, euhedral chromian spinel inclusions. Plagioclase is usually turbid, and some of the hornblende includes olivine.

\section{Hole 894E}

The sediments of Sample 147-894E-1R-2, 66-67 cm, are dominated by calcareous materials and small amounts of basalt particles. The clastic particles are poorly sorted and vary from very coarse sand to pebbles in size. They are extremely poor in detrital mineral grains, although olivine and turbid plagioclase were observed. Some of the basalt is glassy and some is fine grained, which is similar in appearance to that in the Hole 894D sediments. Sporadic olivine phenocrysts with euhedral chromian spinel inclusions were observed in the basalt pebbles (Pl. 1, Fig. 1).

\section{Hole 895A}

Five samples (147-895A-1R-1, 10-12 cm, 22-24 cm, and 35-37 $\mathrm{cm}$, and $147-895 \mathrm{~A}-1 \mathrm{R}-2,31-33 \mathrm{~cm}$, and $36-38 \mathrm{~cm}$ ) were examined for their detrital mineralogy. These sediments are composed of poorly sorted lithic and mineral particles with fine-grained biogenic calcareous materials. The clastic particles vary in size from fine sand to pebbles. Subangular to subrounded particles of serpentinite with a mesh structure, which formed subsequent to the olivine, are abundant (Pl. 1, Fig. 2). Angular particles of fibrous chrysotile serpentine, which commonly form veinlets in serpentinized peridotites, are also prominent. Fine-grained or glassy basalts and dolerites were also 
found as lithic particles. The mineral particles are more angular than the lithic ones.

The detrital minerals are composed of olivine, orthopyroxene, clinopyroxene, chromian spinel, plagioclase, and hornblende, irrespective of the depth of the sample in the Hole 895A core. Some of the chromian spinel is highly anhedral, possibly derived from harzburgite (Pl. 1, Fig. 3), and some is rounded, possibly derived from dunite (Pl. 1, Fig. 4). Chromian spinel is usually altered to magnetite or ferritchromite along cracks ( $\mathrm{Pl}$. 1, Figs. 3 and 4). Some of the olivine is turbid and is similar in appearance to the peridotite olivine.

\section{MINERAL CHEMISTRY \\ Analytical Method}

Minerals were analyzed using an Akashi Alpha30 SEM-EDAX system with an energy-dispersive spectrometer at Kanazawa University. The detection limit is approximately $0.1 \mathrm{wt} \%$ for major oxides except for $\mathrm{Na}_{2} \mathrm{O}$, for which it is approximately $0.3 \mathrm{wt} \%$. The reproducibility of the data is sufficiently good for the major elements. The $\mathrm{Mg} \#$ ( $=\mathrm{Mg} /[\mathrm{Mg}+$ total iron $]$ atomic ratio) of the silicates and the $\mathrm{Cr} \#$ $(=\mathrm{Cr} /[\mathrm{Cr}+\mathrm{Al}]$ atomic ratio $)$ were determined with special care; these ratios are reproducible to about $\pm 0.2 \%$ and about $\pm 0.8 \%$, respectively, on repeated runs.

\section{Chromian Spinel}

Compositions of chromian spinel are shown in Figures 1 through 3 and all analyses are listed in Table 1. Two types of detrital chromian spinel can be distinguished: (1) relatively small euhedra included in basaltic particles and (2) relatively coarse mineral particles commonly associated with serpentine. The former type of spinel was found only in the Site 894 sediments and the latter type of spinel was found only in the Site 895 sediments. As is normal for magmatic chromian spinels, the $\mathrm{Mg \#}$ correlates negatively with the $\mathrm{Cr} \#$ for all spinel grains examined (Fig. 1). The $\mathrm{Fe}^{3+} /\left(\mathrm{Cr}+\mathrm{Al}+\mathrm{Fe}^{3+}\right)$ ratio is very low for both types of spinel (Fig. 2) and the $\mathrm{TiO}_{2}$ content is relatively low, generally less than $1 \mathrm{wt} \%$ and commonly less than $0.5 \mathrm{wt} \%$ (Fig. 3). Both the $\mathrm{Fe}^{3+}$ ratio and the $\mathrm{TiO}_{2}$ content are in the range of spinels in mid-ocean-ridge basalts (MORB) or ocean-floor peridotites (e.g., Dick and Bullen, 1984; Arai, 1992). The $\mathrm{Cr} \#$ is not correlated with the $\mathrm{TiO}_{2}$ content for spinels both from surface sediments and from cored rocks at Hess Deep (Fig. 3). The euhedral spinel in the basalt particles has a high $\mathrm{Mg \#} \mathrm{(approximately} 0.63$ ) and a low Cr\# (approximately 0.34 ). It is within the field of typical MORB spinels in terms of the $\mathrm{Fe}^{3+}-\mathrm{TiO}_{2}$ relation (Arai, 1992).

\section{Silicates}

Phenocryst olivine from Hole 894E, which coexists with chromian spinel with a $\mathrm{Cr} \#=0.34$, is $\mathrm{Fo}_{88-89}$ in composition. Detrital olivine in the Hole $894 \mathrm{D}$ sediments ranges from $\mathrm{Fo}_{86}$ to $\mathrm{Fo}_{90}$ in composition. The magnesian olivine with $\mathrm{FO}_{90}$ is also high in $\mathrm{NiO}(0.3$ to $0.4 \mathrm{wt} \%)$ and in $\mathrm{CaO}(0.3 \mathrm{wt} \%)$. The olivine in the sediments from Hole $895 \mathrm{~A}$ is generally magnesian, $\mathrm{FO}_{90-91}$ in composition, high in $\mathrm{NiO}(0.3$ to $0.4 \mathrm{wt} \%)$, and low in $\mathrm{CaO}(0.1 \mathrm{wt} \%)$.

Orthopyroxene is less common than olivine and is enstatite with a high Mg\# (0.91). The clinopyroxene can be divided into two types in terms of chemistry (Fig. 4). One is augite with an intermediate $\mathrm{Mg}$ \#, from 0.58 to 0.75 , and low $\mathrm{Cr}_{2} \mathrm{O}_{3}$ contents, less than $0.3 \mathrm{wt} \%$. The other is chrome diopside with $0.8-1.3 \mathrm{wt} \% \mathrm{Cr}_{2} \mathrm{O}_{3}$ and a high $\mathrm{Mg}$, mostly $0.91-0.92$.

Hornblende is relatively variable in its chemistry; the $\mathrm{Mg} \#$ ranges from 0.44 to 0.64 and is negatively correlated with the $\mathrm{TiO}_{2}$ content, from 2.3 to $1.0 \mathrm{wt} \%$. Tremolitic amphibole with a very low $\mathrm{Al}_{2} \mathrm{O}_{3}$ content was also found.
Plagioclase is quite variable in composition, from $\mathrm{An}_{81}$ to $\mathrm{An}_{2}$ and most commonly $\mathrm{An}_{50-60}$.

\section{DISCUSSION}

All of the chromian spinel grains, except for the small euhedral ones in basaltic particles, may be derived from olivine-rich plutonic rocks, peridotites, troctolites, and olivine gabbros, as their chemical characteristics are very similar to those of chromian spinel in the drilled rocks (Arai and Matsukage, this volume). Also, the $\mathrm{Cr} \#$ of spinel in peridotites and related mafic plutonic rocks exposed at Hess Deep is relatively constant, at about 0.5 . The relatively low-Ti character of the detrital spinels indicates that their derivation is mainly from harzburgitic rocks (Fig. 3). This is consistent with the predominance of harzburgite over other rocks in Hole 895D, which is located close to Hole $895 \mathrm{~A}$ from which the sediments were obtained (Gillis, Mével, Allan, et al., 1993). Chromian spinel in harzburgite from the drill cores is very low in $\mathrm{TiO}_{2}$, less than $0.2 \mathrm{wt} \%$. The detrital spinel with an intermediate $\mathrm{TiO}_{2}$ content $(0.2$ to $0.5 \mathrm{wt} \%)$ is possibly derived from transitional rocks, from typical harzburgite to dunite, that is, the slightly melt-impregnated harzburgite according to the interpretation of Arai and Matsukage (this volume), who proposed the formation of a dunite-troctolite-olivine gabbro series by an interaction between harzburgite and impregnated melt.

It is noteworthy that lherzolitic peridotites with a $\mathrm{Cr} \#$ of spinel lower than 0.5, which are common from the ocean floor (e.g., Dick and Bullen, 1984; Dick, 1989), are absent at Hess Deep. The oceanic lherzolites are derived mostly from the Atlantic and Indian Oceans, especially from their fracture zones (e.g., Bonatti and Hamlyn, 1978; Dick et al., 1984; Bonatti et al., 1992). The constant and high Cr\# of spinel in harzburgite from Hess Deep strongly indicates that the melting conditions are different between the East Pacific Rise and the Mid-Atlantic or Mid-Indian Ocean Ridges. It is most probable that the degree of partial fusion or the degree of melt extraction at MORB genesis from a source peridotite is higher at the fast-spreading ridge system than at the slow-spreading one. It may be especially low in the neighborhood of fracture zones at the latter.

Hornblende and some olivine and plagioclase grains from the sediments from Hole 894D are coarse and are possibly derived from gabbroic rocks, although the shipboard description suggests that the sediments are composed mainly of basaltic sand (Gillis, Mével, Allan, et al., 1993). An olivine phenocryst in a basalt particle of the sediments from Hole $894 \mathrm{E}$ is magnesian $\left(\mathrm{Fo}_{88-89}\right)$ and coexists with chromian spinel with $\mathrm{Cr} \#=0.34$. This indicates that the basalt is primitive, possible primary, and can coexist with a lherzolitic peridotite (Arai, 1994). Detrital olivine can be divided into two groups: low $\mathrm{Ca}(\mathrm{CaO} 0.1 \mathrm{wt} \%)$ and high $\mathrm{Ca}(\mathrm{CaO} 0.3 \mathrm{wt} \%)$ (Table 2). The former is high both in Fo (90-91) and in $\mathrm{NiO}(0.3$ to $0.4 \mathrm{wt} \%)$ contents and is probably derived from peridotites. The latter may be derived from some basaltic rocks. Olivine in gabbroic rocks, which has a $\mathrm{CaO}$ content as low as peridotite olivine and has variable but low Fo and $\mathrm{NiO}$ contents (Arai and Matsukage, this volume), was not found in the surface sediments. Orthopyroxene, which has high a $\mathrm{Mg} \#(0.91)$ in the Hole $895 \mathrm{~A}$ sediments, is similar in chemistry and appearance to that in the cored harzburgite (Arai and Matsukage, this volume). Augite is possibly derived from gabbroic rocks because the basaltic rocks are too $\mathrm{Mg}$ rich, as deduced from the high $\mathrm{Mg \#}$ of possible olivine phenocrysts $\left(\mathrm{Fo}_{88-90}\right)$ discussed above, to contain augite with an intermediate $\mathrm{Mg} \#$ ( 0.58 to 0.75$)$. Chrome diopside with a high $\mathrm{Mg} \#$, mostly $0.91-0.92$, is derived from peridotites.

In summary, the detrital mineralogy is similar to the cored rock mineralogy. Therefore, it is probable that the detrital minerals from the Site 894 sediments are derived mostly from gabbroic rocks and those from the Hole 895 sediments from peridotites and gabbros. 
Table 1. Electron microprobe analyses of the detrital chromian spinels from Hess Deep.

\begin{tabular}{|c|c|c|c|c|c|c|c|c|c|c|c|}
\hline Hole: & \multicolumn{2}{|c|}{$894 \mathrm{E}$} & \multicolumn{9}{|c|}{$895 \mathrm{~A}$} \\
\hline $\mathrm{TiO}_{2}$ & 0.30 & 0.49 & 0.13 & 0.26 & 0.34 & 0.86 & 0.07 & 0.15 & 0.25 & 0.04 & 0.05 \\
\hline $\mathrm{Al}_{2} \mathrm{O}_{3}$ & 37.18 & 36.35 & 30.96 & 26.51 & 25.89 & 20.76 & 25.73 & 26.67 & 23.76 & 23,08 & 27.11 \\
\hline $\mathrm{Cr}_{2} \mathrm{O}_{3}$ & 29.13 & 29.79 & 36.18 & 42.08 & 42.50 & 44.87 & 42.08 & 41.03 & 41.66 & 41.47 & 40.84 \\
\hline $\mathrm{FeO}^{*}$ & 15.15 & 15.05 & 17.91 & 16.69 & 17.07 & 22.29 & 19.22 & 17.64 & 22.19 & 23.31 & 17.52 \\
\hline $\mathrm{MnO}$ & 0.11 & 0.46 & 0.00 & 0.35 & 0.31 & 0.43 & 0.39 & 0.50 & 0.48 & 0.47 & 0.00 \\
\hline $\mathrm{MgO}$ & 16.83 & 16.58 & 14.10 & 13.58 & 13.10 & 10.21 & 12.25 & 13.21 & 11.32 & 11.05 & 14.09 \\
\hline $\mathrm{NiO}$ & 0.31 & 0.32 & 0.25 & 0.05 & 0.17 & 0.09 & 0.11 & 0.21 & 0.10 & 0.17 & 0.14 \\
\hline Total & 99.02 & 99.05 & 99.52 & 99.53 & 99.38 & 99.51 & 99.86 & 99.41 & 99.75 & 99.58 & 99.75 \\
\hline $\mathrm{Ti}$ & 0.007 & 0.011 & 0.003 & 0.006 & 0.008 & 0.021 & 0.002 & 0.004 & 0.006 & 0.001 & 0.001 \\
\hline $\mathrm{Al}$ & 1.263 & 1.239 & 1,089 & 0.949 & 0.932 & 0.780 & 0.931 & 0.959 & 0.877 & 0.860 & 0.967 \\
\hline $\mathrm{Cr}$ & 0.663 & 0.681 & 0.854 & 1.010 & 1.027 & 1.131 & 1.022 & 0.990 & 1.032 & 1.036 & 0.977 \\
\hline $\mathrm{Fe}^{*}$ & 0.365 & 0.364 & 0.447 & 0.424 & 0.436 & 0.594 & 0.494 & 0.450 & 0.581 & 0.616 & 0.443 \\
\hline $\mathrm{Mn}$ & 0.003 & 0.011 & 0.000 & 0.009 & 0.008 & 0.012 & 0.010 & 0.013 & 0.013 & 0.013 & 0.000 \\
\hline $\mathrm{Mg}$ & 0.723 & 0.715 & 0.627 & 0.615 & 0.597 & 0.485 & 0.561 & 0.601 & 0.529 & 0.521 & 0.635 \\
\hline $\mathrm{Ni}$ & 0.007 & 0.008 & 0.006 & 0.001 & 0.004 & 0.002 & 0.003 & 0.005 & 0.003 & 0.004 & 0.003 \\
\hline Total & 3.030 & 3.029 & 3.026 & 3.014 & 3.012 & 3.024 & 3.022 & 3.022 & 3.040 & 3.051 & 3.027 \\
\hline $\mathrm{Mg \#}$ & 0.723 & 0.720 & 0.625 & 0.618 & 0.602 & 0.494 & 0.560 & 0.602 & 0.527 & 0.515 & 0.631 \\
\hline $\mathrm{Cr} \#$ & 0.344 & 0.355 & 0.439 & 0.516 & 0.524 & 0.592 & 0.523 & 0.508 & 0.541 & 0.547 & 0.503 \\
\hline $\mathrm{Cr} /\left(\mathrm{Cr}+\mathrm{Al}+\mathrm{Fe}^{3+}\right)$ & 0.332 & 0.343 & 0.425 & 0.507 & 0.517 & 0.575 & 0.510 & 0.496 & 0.515 & 0.513 & 0.485 \\
\hline $\mathrm{Al} /\left(\mathrm{Cr}+\mathrm{Al}+\mathrm{Fe}^{3+}\right)$ & 0.631 & 0.624 & 0.543 & 0.477 & 0.470 & 0.397 & 0.465 & 0.481 & 0.438 & 0.425 & 0.480 \\
\hline $\mathrm{Fe}^{3+} /\left(\mathrm{Cr}+\mathrm{Al}+\mathrm{Fe}^{34}\right)$ & 0.037 & 0.033 & 0.032 & 0.016 & 0.013 & 0.028 & 0.025 & 0.023 & 0.048 & 0.062 & 0.035 \\
\hline
\end{tabular}

Notes: Cation fractions calculated assuming spinel stoichiometry. All Ti assumed to form the ulvöspinel molecule, $\mathrm{Fe}^{2+}{ }_{2} \mathrm{TiO}_{4} \cdot \mathrm{FeO} *$ and $\mathrm{Fe} *$ indicate total iron as $\mathrm{FeO}$ and $\mathrm{Fe}$, respectively. $\mathrm{Mg} \#$ and $\mathrm{Cr} \#$ are $\mathrm{Mg} /\left(\mathrm{Mg}+\mathrm{Fe}^{2+}\right)$ and $\mathrm{Cr} /(\mathrm{Cr}+\mathrm{Al})$ atomic ratios, respectively.

\begin{tabular}{|c|c|c|c|c|c|c|c|c|c|c|}
\hline Hole: & \multicolumn{10}{|c|}{$\begin{array}{c}895 \mathrm{~A} \\
\text { (continued). }\end{array}$} \\
\hline $\mathrm{TiO}_{2}$ & 0.01 & 0.12 & 0.72 & 0.10 & 0.32 & 0.10 & 0.02 & 0.00 & 0.23 & 0.21 \\
\hline $\mathrm{Al}_{2} \mathrm{O}_{3}$ & 25.49 & 29.60 & 26.71 & 24.76 & 25.63 & 24.42 & 29.05 & 26.45 & 25.79 & 26.01 \\
\hline $\mathrm{Cr}_{2} \mathrm{O}_{3}$ & 43.59 & 38.61 & 39.16 & 42.76 & 39.30 & 42.17 & 38.14 & 42.14 & 41.38 & 41.86 \\
\hline $\mathrm{FeO}^{*}$ & 16.43 & 17.04 & 19.05 & 18.78 & 22.76 & 19.75 & 19.01 & 16.59 & 18.71 & 17.66 \\
\hline $\mathrm{MnO}$ & 0.00 & 0.00 & 0.00 & 0.54 & 0.53 & 0.55 & 0.55 & 0.44 & 0.75 & 0.54 \\
\hline $\mathrm{MgO}$ & 14.08 & 14.28 & 13.87 & 12.27 & 11.09 & 12.35 & 12.37 & 13.48 & 12.36 & 13.08 \\
\hline $\mathrm{NiO}$ & 0.18 & 0.22 & 0.24 & 0.19 & 0.00 & 0.12 & 0.09 & 0.18 & 0.17 & 0.28 \\
\hline Total & 99.78 & 99.87 & 99.76 & 99.41 & 99.64 & 99.47 & 99.22 & 99.28 & 99.40 & 99.63 \\
\hline $\mathrm{Ti}$ & 0.000 & 0.003 & 0.016 & 0.002 & 0.007 & 0.002 & 0.000 & 0.000 & 0.005 & 0.005 \\
\hline $\mathrm{Al}$ & 0.913 & 1.041 & 0.957 & 0.903 & 0.941 & 0.894 & 1.041 & 0.950 & 0.936 & 0.937 \\
\hline $\mathrm{Cr}$ & 1.047 & 0.911 & 0.941 & 1.046 & 0.968 & 1.035 & 0.917 & 1.016 & 1.008 & 1.011 \\
\hline $\mathrm{Fe}^{*}$ & 0.417 & 0.425 & 0.484 & 0.486 & 0.593 & 0.513 & 0.484 & 0.423 & 0.482 & 0.451 \\
\hline $\mathrm{Mn}$ & 0.000 & 0.000 & 0.000 & 0.014 & 0.014 & 0.015 & 0.014 & 0.011 & 0.020 & 0.014 \\
\hline $\mathrm{Mg}$ & 0.638 & 0.635 & 0.629 & 0.566 & 0.515 & 0.572 & 0.561 & 0.612 & 0.568 & 0.596 \\
\hline $\mathrm{Ni}$ & 0.004 & 0.005 & 0.006 & 0.005 & 0.000 & 0.003 & 0.002 & 0.004 & 0.004 & 0.007 \\
\hline Total & 3.020 & 3.021 & 3.034 & 3.023 & 3.038 & 3.033 & 3.020 & 3.017 & 3.023 & 3.021 \\
\hline $\mathrm{Mg \#}$ & 0.635 & 0.634 & 0.633 & 0.567 & 0.515 & 0.570 & 0.560 & 0.612 & 0.571 & 0.599 \\
\hline $\mathrm{Cr} \#$ & 0.534 & 0.467 & 0.496 & 0.537 & 0.507 & 0.537 & 0.468 & 0.517 & 0.518 & 0.519 \\
\hline $\mathrm{Cr} /\left(\mathrm{Cr}+\mathrm{Al}+\mathrm{Fe}^{2 *}\right)$ & 0.521 & 0.454 & 0.474 & 0.524 & 0.484 & 0.516 & 0.458 & 0.508 & 0.507 & 0.508 \\
\hline $\mathrm{Al} /\left(\mathrm{Cr}+\mathrm{Al}+\mathrm{Fe}^{4+}\right)$ & 0.454 & 0.519 & 0.482 & 0.452 & 0.470 & 0.446 & 0.520 & 0.475 & 0.471 & 0.471 \\
\hline $\mathrm{Fe}^{3 *} /\left(\mathrm{Cr}+\mathrm{Al}+\mathrm{Fe}^{3+}\right)$ & 0.025 & 0.026 & 0.044 & 0.024 & 0.046 & 0.038 & 0.021 & 0.017 & 0.023 & 0.021 \\
\hline
\end{tabular}

\section{CONCLUSIONS}

The sediments from Site 894 are derived from basalts and gabbros. Those from Site 895 are derived from peridotites and gabbros. The detrital chromian spinels are generally $\mathrm{TiO}_{2}$ poor, which possibly indicates the predominance of harzburgite or the peridotite transitional from harzburgite to dunite (i.e., the slightly melt-impregnated harzburgite) in the mantle rocks exposed at Hess Deep. The peridotites that supplied the clastic materials are generally less melt impregnated than the cored peridotitic suites recovered during Leg 147. Lherzolitic peridotites, which are common in the Atlantic and Indian Oceans, are absent at Hess Deep.

\section{ACKNOWLEDGMENTS}

S.A. wishes to express his hearty appreciation to K. Gillis, C. Mével, J. Allan, other shipboard scientists, marine technicians, and the captain and crew of JOIDES Resolution during the Leg 147 cruise for their collaboration and hospitality. S.A. is greatly indebted to A.
Taira for the trouble he took to send S.A. on the ODP cruise. We are grateful to K. Matsukage for her suggestions and discussion. Critical comments by J. Allan, M. Clynne, and G. Gaetani greatly helped improve the manuscript.

\section{REFERENCES}

Arai, S., 1992. Chemistry of chromian spinels in volcanic rocks as a potential guide to magma chemistry. Mineral. Mag., 56:173-184.

, 1994. Compositional variation of olivine-chromian spinel in $\mathrm{Mg}$ rich magmas as a guide to their residual spinel peridotites. J. Volcanol. Geotherm. Res., 59:279-293.

Arai, S., Ito, T., and Ozawa, K., 1983. Ultramafic-mafic clastic rocks from the Mineoka belt, central Japan. Chishitsugaku Zasshi [J. Geol. Soc. Jpn.], 89:287-297. (in Japanese with English abstract)

Arai, S., and Okada, H., 1991. Petrology of serpentine sandstone as a key to tectonic development of serpentine belts. Tectonophysics, 195:65-81.

Bonatti, E., Emiliani, C., Ferrara, G., Honnorez, J., and Rydell, H., 1974. Ultramafic-carbonate breccias from the equatorial Mid-Atlantic Ridge. Mar. Geol., 16:83-102.

Bonatti, E., and Hamlyn, P.R., 1978. Mantle uplifted block in the western Indian Ocean. Science, 201:249-251. 
Bonatti, E., Honnorez, J., and Gartner, S., Jr., 1973. Sedimentary serpentinites from the Mid-Atlantic Ridge. J. Sediment. Petrol., 43:728-735.

Bonatti, E., Peyve, A., Kepezhinskas, P., Kurentsova, N., Seyler, M., Skolotnev, S., and Udintsev, G., 1992. Upper mantle heterogeneity below the Mid-Atlantic Ridge, $0^{\circ}-15^{\circ}$ N. J. Geophys. Res., 97:4461-4476.

Dick, H.J.B., 1989. Abyssal peridotites, very slow spreading ridges and ocean ridge magmatism. In Saunders, A.D., and Norry, M.J. (Eds.), Magmatism in the Ocean Basins. Geol. Soc. Spec. Publ. London, 42:71-105.

Dick, H.J.B., and Bullen, T., 1984. Chromian spinel as a petrogenetic indicator in abyssal and alpine-type peridotites and spatially associated lavas. Contrib. Mineral. Petrol., 86:54-76.

Dick, H.J.B., Fisher, R.L., and Bryan, W.B., 1984. Mineralogic variability of the uppermost mantle along mid-ocean ridges. Earth Planet. Sci. Lett., 69:88-106.

Evans, B.W., and Frost, R.F., 1975. Chrome-spinel in progressive metamorphism-a preliminary analysis. Geochim. Cosmochim. Acta, 39:957972.

Francheteau, J., Armijo, R., Cheminée, J.L., Hekinian, R., Lonsdale, P., and Blum, N., 1990. 1 Ma East Pacific Rise oceanic crust and uppermost

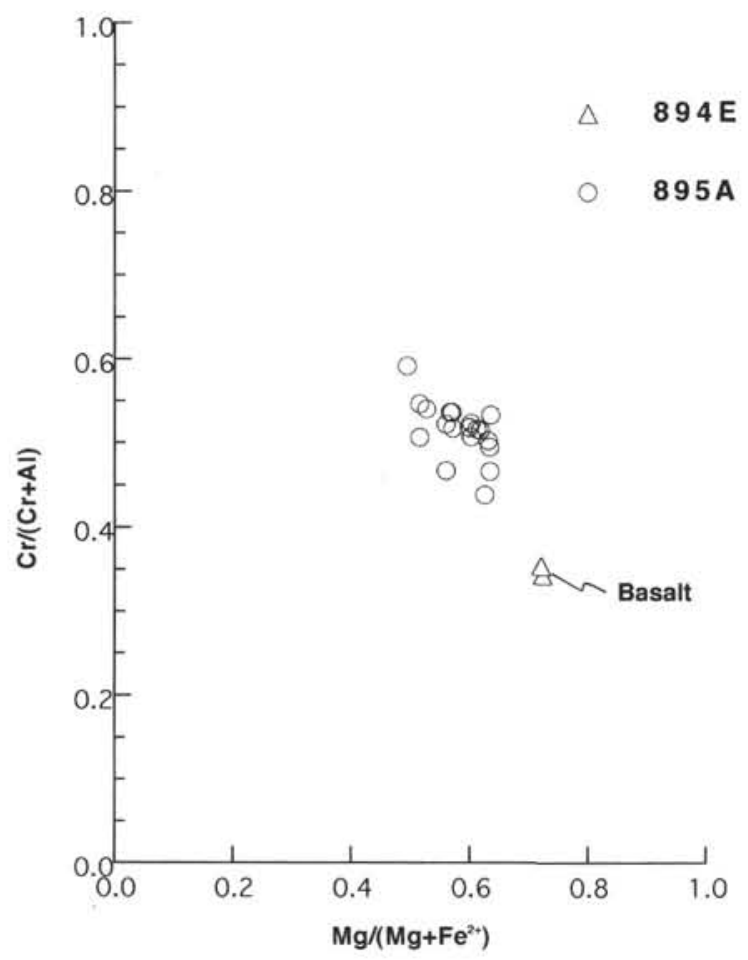

Figure 1. Relationship between the $\mathrm{Cr} /(\mathrm{Cr}+\mathrm{Al})$ and $\mathrm{Mg} /\left(\mathrm{Mg}+\mathrm{Fe}^{2+}\right)$ atomic ratios of the detrital chromian spinel from Hess Deep. mantle exposed by rifting in Hess Deep (equatorial Pacific Ocean). Earth Planet. Sci. Lett., 101:281-295.

1992. Dyke complex of the East Pacific Rise exposed in the walls of Hess Deep and the structure of the upper oceanic crust. Earth Planet. Sci. Lett., 111:109-121.

Gillis, K., Mével, C., Allan, J., et al., 1993. Proc. ODP, Init. Repts., 147: College Station, TX (Ocean Drilling Program).

Irvine, T.N., 1967. Chromium spinel as a petrogenetic indicator. Part 2: Petrological applications. Can. J. Earth Sci., 4:71-103.

Jackson, E.D., 1969. Chemical variation in co-existing chromite and olivine in chromite zones of the Stillwater complex. In Wilson, H.D.B. (Ed.), Magmatic Ore Deposits. Econ. Geol. Monogr., 6:41-71.

Date of initial receipt: 2 August 1994

Date of acceptance: 29 November 1994

Ms 147SR-006

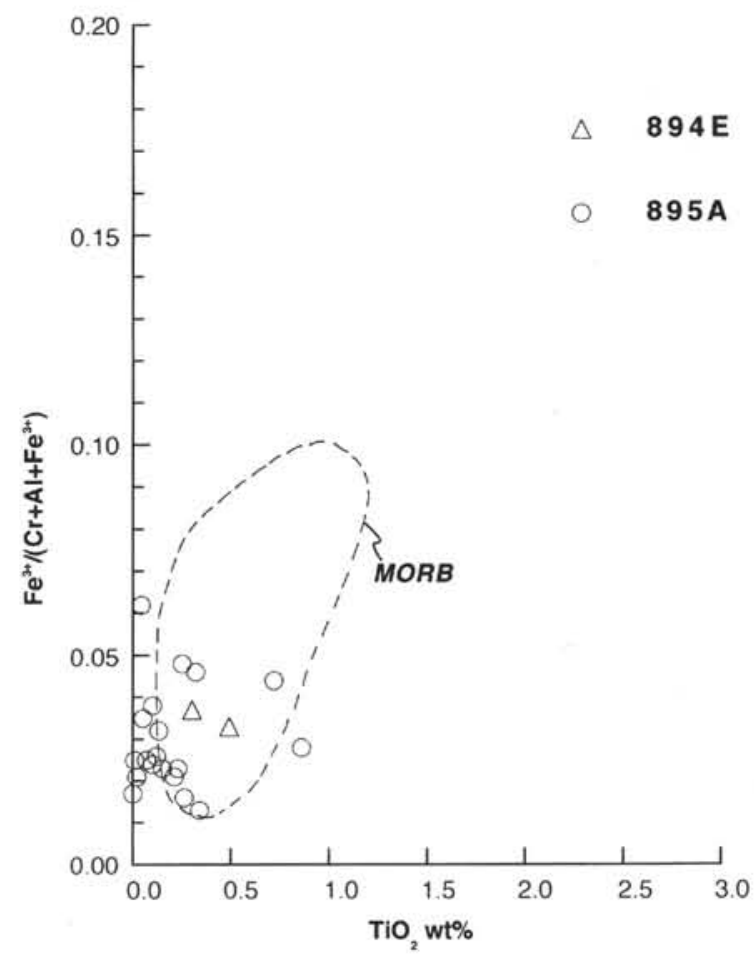

Figure 2. Relationship between the $\mathrm{Fe}^{3+} /\left(\mathrm{Cr}+\mathrm{Al}+\mathrm{Fe}^{3+}\right)$ atomic ratio and $\mathrm{TiO}_{2}$ content of the detrital chromian spinel from Hess Deep. The MORB field is after Arai (1992). 


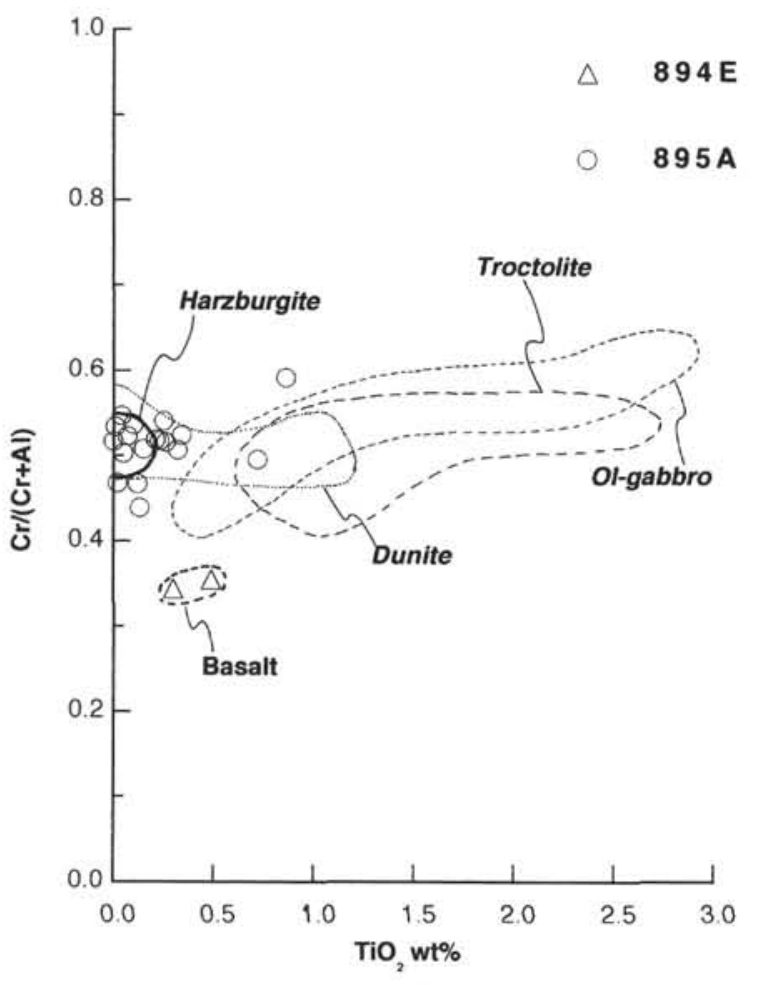

Figure 3. Relationship between the $\mathrm{Cr} /(\mathrm{Cr}+\mathrm{Al})$ atomic ratio and $\mathrm{TiO}_{2}$ content of the detrital chromian spinel from Hess Deep. The regions for cored rocks of Site 895 are after Arai and Matsukage (this volume).

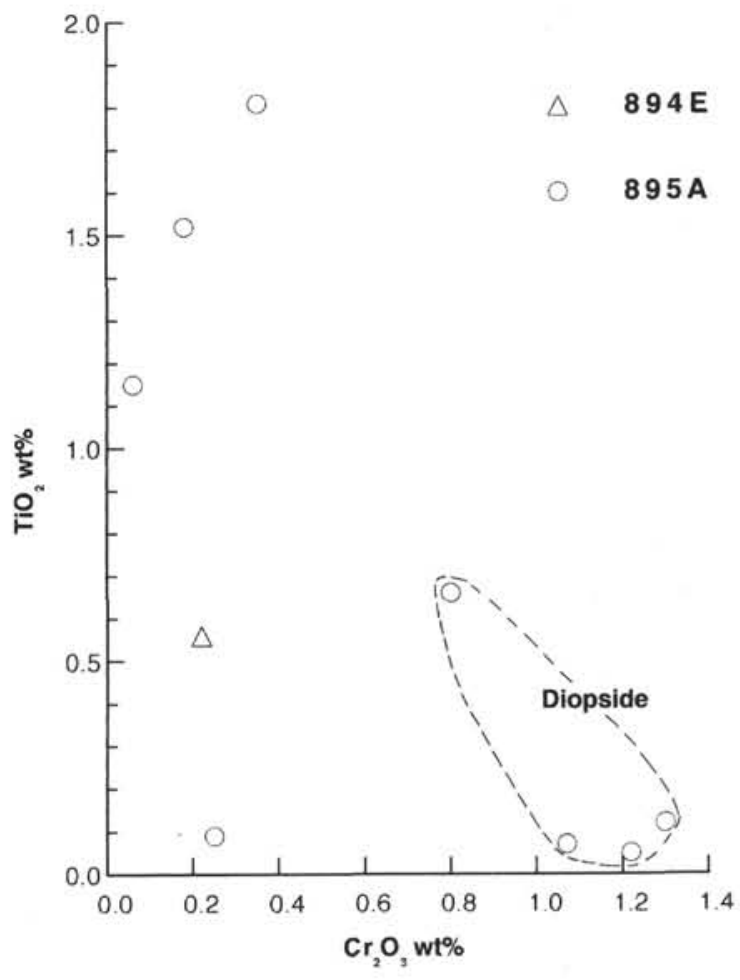

Figure 4. Relationship between the $\mathrm{TiO}_{2}$ content and $\mathrm{Cr} \#$ of the detrital clinopyroxenes from Hess Deep. 
Table 2. Electron microprobe analyses of the detrital silicate minerals from Hess Deep.

\begin{tabular}{|c|c|c|c|c|c|c|c|c|c|c|c|c|c|c|}
\hline \multirow[b]{3}{*}{$\mathrm{SiO}_{2}$} & \multicolumn{12}{|c|}{$894 \mathrm{D}$} & \multirow{2}{*}{\multicolumn{2}{|c|}{$\begin{array}{c}894 \mathrm{E} \\
\text { Olivine }\end{array}$}} \\
\hline & \multicolumn{4}{|c|}{ Olivine } & \multirow{2}{*}{$\begin{array}{c}\text { Clinopyroxene } \\
51.47\end{array}$} & \multicolumn{5}{|c|}{ Plagioclase } & \multicolumn{2}{|c|}{ Hornblende } & & \\
\hline & 40.32 & 41.07 & 41.10 & 40.20 & & 67.10 & 68.39 & 55.68 & 55.42 & 47.23 & 49.47 & 49.10 & 40.69 & 40.45 \\
\hline $\mathrm{TiO}_{2}$ & 0.04 & 0.13 & 0.15 & 0.01 & 0.56 & 0.02 & 0.00 & 0.12 & 0.11 & 0.10 & 1.27 & 1.01 & 0.01 & 0.07 \\
\hline $\mathrm{Al}_{2} \mathrm{O}_{3}$ & 0.33 & 0.14 & 0.44 & 0.40 & 1.80 & 20.36 & 19.86 & 27.96 & 28.31 & 33.19 & 15.12 & 15.93 & 0.36 & 0.34 \\
\hline $\mathrm{Cr}_{2} \mathrm{O}_{3}$ & 0.14 & 0.15 & 0.07 & 0.10 & 0.22 & 0.04 & 0.01 & 0.05 & 0.00 & 0.11 & 0.14 & 0.08 & 0.06 & 0.16 \\
\hline $\mathrm{FeO}^{*}$ & 13.15 & 9.74 & 9.49 & 13.51 & 10.78 & 0.09 & 0.13 & 0.48 & 0.37 & 0.37 & 9.37 & 8.47 & 11.25 & 11.63 \\
\hline $\mathrm{MnO}$ & 0.26 & 0.24 & 0.09 & 0.26 & 0.32 & 0.07 & 0.05 & 0.01 & 0.02 & 0.11 & 0.19 & 0.18 & 0.15 & 0.23 \\
\hline $\mathrm{MgO}$ & 45.55 & 48.33 & 48.46 & 45.07 & 13.47 & 0.00 & 0.00 & 0.00 & 0.00 & 0.17 & 7.92 & 8.45 & 47.16 & 46.69 \\
\hline $\mathrm{CaO}$ & 0.42 & 0.31 & 0.32 & 0.46 & 20.46 & 1.05 & 0.19 & 10.83 & 10.43 & 17.21 & 11.57 & 12.01 & 0.31 & 0.39 \\
\hline $\mathrm{Na}_{2} \mathrm{O}$ & 0.00 & 0.00 & 0.01 & 0.00 & 0.33 & 10.73 & 11.23 & 4.52 & 5.19 & 1.34 & 2.21 & 1.92 & 0.00 & 0.00 \\
\hline $\mathrm{K}_{2} \mathrm{O}$ & 0.01 & 0.01 & 0.00 & 0.06 & 0.00 & 0.09 & 0.00 & 0.08 & 0.13 & 0.00 & 0.04 & 0.03 & 0.00 & 0.00 \\
\hline $\mathrm{NiO}$ & 0.18 & 0.31 & 0.35 & 0.21 & 0.08 & 0.08 & 0.05 & 0.00 & 0.00 & 0.00 & 0.05 & 0.10 & 0.30 & 0.29 \\
\hline Total & 100.39 & 100.42 & 100.50 & 100.28 & 99.49 & 99.62 & 99.92 & 99.72 & 100.00 & 99.85 & 97.35 & 97.27 & 100.31 & 100.25 \\
\hline $\begin{array}{l}\mathrm{Mg} \# \\
\mathrm{An}\end{array}$ & 0.861 & 0.898 & 0.901 & 0.856 & 0.690 & 5.70 & 1.90 & 48.80 & 50.30 & 80.30 & 0.601 & 0.640 & 0.882 & 0.877 \\
\hline
\end{tabular}

Notes: $\mathrm{FeO}^{*}$ and $\mathrm{Fe}^{*}$ are total iron as $\mathrm{FeO}$ and $\mathrm{Fe}$, respectively. $\mathrm{Mg} \#$ is $\mathrm{Mg}\left(\mathrm{Me}+\mathrm{Fe}^{*}\right)$ atomic ratio.

\begin{tabular}{|c|c|c|c|c|c|c|c|c|c|c|c|c|c|c|c|c|}
\hline \multirow[b]{3}{*}{$\mathrm{SiO}_{2}$} & \multicolumn{16}{|c|}{$895 \mathrm{~A}$} \\
\hline & \multicolumn{11}{|c|}{ Olivine } & \multicolumn{5}{|c|}{ Clinopyroxene } \\
\hline & 41.17 & 41.29 & 41.56 & 41.31 & 40.98 & 41.19 & 41.40 & 40.97 & 40.98 & 40.90 & 41.31 & 50.62 & 52.85 & 52.14 & 49.65 & 52.15 \\
\hline $\mathrm{TiO}_{2}^{2}$ & 0.04 & 0.06 & 0.00 & 0.31 & 0.06 & 0.00 & 0.13 & 0.00 & 0.00 & 0.14 & 0.03 & 1.15 & 0.09 & 0.66 & 1.52 & 0.05 \\
\hline $\mathrm{Al}_{2} \mathrm{O}_{3}$ & 0.16 & 0.35 & 0.36 & 0.26 & 0.24 & 0.14 & 0.17 & 0.27 & 0.30 & 0.18 & 0.18 & 2.00 & 0.82 & 2.55 & 4.28 & 3.30 \\
\hline $\mathrm{Cr}_{2} \mathrm{O}_{3}$ & 0.13 & 0.00 & 0.05 & 0.00 & 0.00 & 0.09 & 0.09 & 0.00 & 0.07 & 0.10 & 0.00 & 0.06 & 0.26 & 0.80 & 0.18 & 1.22 \\
\hline $\mathrm{FeO}^{*}$ & 9.18 & 8.87 & 8.53 & 8.88 & 8.56 & 8.38 & 8.47 & 9.21 & 8.68 & 8.76 & 9.10 & 16.07 & 8.31 & 4.00 & 10.45 & 2.87 \\
\hline $\mathrm{MnO}$ & 0.05 & 0.17 & 0.17 & 0.08 & 0.08 & 0.17 & 0.17 & 0.07 & 0.16 & 0.21 & 0.09 & 0.46 & 0.39 & 0.13 & 0.21 & 0.00 \\
\hline $\mathrm{MgO}$ & 49.16 & 49.16 & 49.31 & 49.19 & 49.87 & 49.81 & 49.59 & 49.25 & 49.89 & 49.68 & 49.08 & 12.20 & 14.04 & 17.43 & 16.54 & 17.75 \\
\hline $\mathrm{CaO}$ & 0.14 & 0.12 & 0.11 & 0.15 & 0.10 & 0.07 & 0.13 & 0.10 & 0.07 & 0.07 & 0.15 & 16.67 & 22.51 & 21.61 & 15.99 & 21.90 \\
\hline $\mathrm{Na}_{2} \mathrm{O}$ & 0.00 & 0.00 & 0.00 & 0.00 & 0.00 & 0.00 & 0.00 & 0.00 & 0.00 & 0.00 & 0.00 & 0.00 & 0.00 & 0.00 & 0.15 & 0.00 \\
\hline $\mathrm{K}_{2} \mathrm{O}$ & 0.01 & 0.00 & 0.00 & 0.00 & 0.06 & 0.03 & 0.00 & 0.01 & 0.00 & 0.00 & 0.04 & 0.00 & 0.03 & 0.00 & 0.04 & 0.00 \\
\hline $\mathrm{NiO}$ & 0.33 & 0.49 & 0.31 & 0.32 & 0.47 & 0.46 & 0.36 & 0.56 & 0.31 & 0.43 & 0.36 & 0.25 & 0.01 & 0.09 & 0.11 & 0.09 \\
\hline Total & 100.37 & 100.50 & 100.41 & 100.50 & 100.43 & 100.35 & 100.50 & 100.44 & 100.47 & 100.48 & 100.36 & 99.48 & 99.31 & 99.40 & 99.13 & 99.33 \\
\hline $\begin{array}{l}\mathrm{Mg} \# \\
\mathrm{An}\end{array}$ & 0.905 & 0.908 & 0.912 & 0.908 & 0.912 & 0.914 & 0.913 & 0.905 & 0.911 & 0.910 & 0.906 & 0.575 & 0.751 & 0.886 & 0.738 & 0.917 \\
\hline
\end{tabular}

\begin{tabular}{|c|c|c|c|c|c|c|c|c|c|c|c|c|c|}
\hline \multirow[b]{3}{*}{$\mathrm{SiO}_{2}$} & \multicolumn{13}{|c|}{$895 \mathrm{~A}$} \\
\hline & \multicolumn{3}{|c|}{ Clinopyroxene } & \multicolumn{2}{|c|}{ Orthopyroxene } & \multicolumn{4}{|c|}{ Plagioclase } & \multicolumn{4}{|c|}{ Hornblende } \\
\hline & 52.65 & 49.18 & 52.63 & 56.22 & 55.87 & 62.41 & 55.28 & 53.80 & 53.11 & 51.72 & 48.55 & 50.17 & 49.06 \\
\hline $\mathrm{TiO}_{2}$ & 0.07 & 1.81 & 0.12 & 0.07 & 0.13 & 0.04 & 0.07 & 0.10 & 0.24 & 2.35 & 1.28 & 2.19 & 1.22 \\
\hline $\mathrm{Al}_{2} \mathrm{O}_{3}$ & 2.39 & 4.54 & 2.53 & 2.55 & 2.29 & 23.03 & 27.59 & 28.65 & 27.63 & 13.91 & 16.19 & 13.74 & 15.85 \\
\hline $\mathrm{Cr}_{2} \mathrm{O}_{3}$ & 1.07 & 0.35 & 1.30 & 0.80 & 0.77 & 0.04 & 0.17 & 0.11 & 0.18 & 0.10 & 0.13 & 0.19 & 0.16 \\
\hline $\mathrm{FeO}^{*}$ & 2.46 & 9.35 & 2.79 & 5.83 & 5.68 & 0.76 & 1.15 & 1.12 & 1.23 & 12.70 & 8.66 & 12.31 & 8.78 \\
\hline $\mathrm{MnO}$ & 0.18 & 0.17 & 0.04 & 0.21 & 0.15 & 0.03 & 0.03 & 0.03 & 0.11 & 0.27 & 0.13 & 0.11 & 0.17 \\
\hline $\mathrm{MgO}$ & 17.49 & 14.73 & 17.16 & 32.28 & 32.37 & 0.00 & 0.26 & 0.00 & 0.00 & 5.68 & 8.66 & 6.27 & 8.32 \\
\hline $\mathrm{CaO}$ & 22.85 & 18.93 & 22.60 & 2.14 & 2.92 & 5.05 & 10.17 & 12.07 & 12.41 & 10.45 & 11.61 & 10.32 & 11.48 \\
\hline $\mathrm{Na}_{2} \mathrm{O}$ & 0.00 & 0.00 & 0.00 & 0.00 & 0.00 & 8.19 & 5.13 & 3.89 & 4.79 & 1.56 & 1.87 & 1.58 & 2.28 \\
\hline $\mathrm{K}, \mathrm{O}$ & 0.00 & 0.00 & 0.00 & 0.03 & 0.02 & 0.21 & 0.05 & 0.05 & 0.15 & 0.22 & 0.09 & 0.12 & 0.01 \\
\hline $\mathrm{NiO}$ & 0.01 & 0.09 & 0.08 & 0.27 & 0.09 & 0.08 & 0.00 & 0.01 & 0.00 & 0.00 & 0.00 & 0.07 & 0.00 \\
\hline Total & 99.17 & 99.16 & 99.25 & 100.39 & 100.29 & 99.83 & 99.90 & 99.84 & 99.85 & 98.96 & 97.16 & 97.07 & 97.33 \\
\hline $\mathrm{Mg \#}$ & 0.927 & 0.737 & 0.917 & 0.908 & 0.910 & & & & & 0.444 & 0.641 & 0.476 & 0.628 \\
\hline An & & & & & & 21.70 & 50.00 & 54.60 & 53.10 & & & & \\
\hline
\end{tabular}



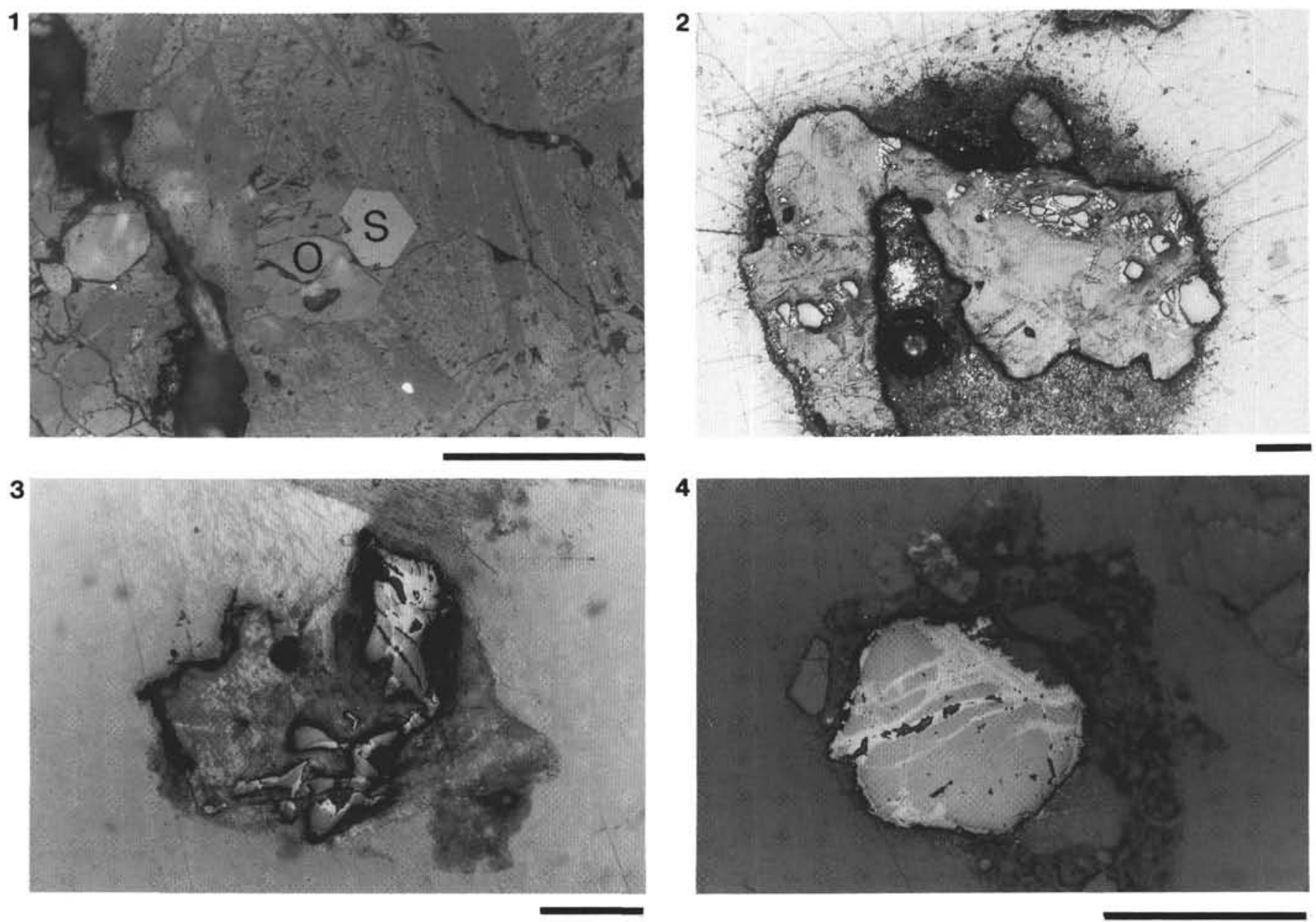

Plate 1. Reflected-light photomicrographs of clastic particles in the surface sediments from Hess Deep. Scale bar is $0.2 \mathrm{~mm}$. 1. Olivine phenocryst (O) with euhedral spinel (S) in a basalt pebble from Hole 894E. 2. Subrounded particle of serpentinized peridotite from Hole 895A. The relic olivine has high relief. Note that the original shape of the particle was destroyed during sample processing. 3. Highly anhedral chromian spinel particle from Hole 895A, possibly derived from harzburgite. 4. Subhedral chromian spinel particle from Hole 895A, possibly derived from dunite. 